\title{
MINERAL RESOURCE POTENTIAL OF THE OVERFLOW ROADLESS AREA, RABUN COUNTY, GEORGIA, AND MACON COUNTY, NORTH CAROLINA
}

\author{
By \\ Robert P. Koeppen and Arthur E. Nelson, U.S. Geological Survey \\ and
}

Michael P. Davis, U.S. Bureau of Mines

1983

Studies Related to Wilderness

Under the provisions of the Wilderness Act (Public Law 88-577, September 3, 1964) and related acts, the U.S. Geological Survey and the U.S. Bureau of Mines have been conducting mineral surveys of wilderness and primitive areas. Areas officially designated as "wilderness," "wild," or "canoe" when the act was passed were incorporated into the National Wilderness Preservation System, and some of them are presently being studied. The act provided that areas under consideration for wilderness designation should be studied for suitability for incorporation into the Wilderness System. The mineral surveys constitute one aspect of the suitability studies. The act directs that the results of such surveys are to be made available to the public and be submitted to the President and the Congress. This report discusses the results of a mineral survey of the Overflow Roadless Area (08-026) in the Chattahoochee National Forest, Rabun County, Ga., and the Nantahala National Forest, Macon County, N. C. The area was classified as a further planning area during the Second Roadless Area Review and Evaluation (RARE II) by the U.S. Forest Service, January 1979.

\section{MINERAL RESOURCE POTENTIAL SUMMARY STATEMENT}

The Overflow Roadless Area is on the western edge of the Hall County gold belt, a 2-mi-wide band of isolated gold-bearing quartz veins and associated placers that have been prospected and worked since the 1800 's, but no records exist of gold occurrences or mining activity within the roadless area. Geochemical data from rocks, pan-concentrated heavy minerals, and fine-grained stream sediments do not reveal any anomalous concentrations of trace elements that might be related to hidden mineral deposits. Minor isolated deposits of amethyst gemstone and mica pegmatite occur within the area. Rock suitable for use as crushed stone and aggregate is abundant both in and adjacent to the roadless area. Paleozoic sedimentary rocks that probably underlie the metamorphic rocks exposed at the surface at depths of about $5 \mathrm{mi}$ have an unknown potential for hydrocarbons in the form of natural gas. No reasonable estimate of this potential can be made with available information.

\section{INTRODUCTION}

The Overflow Roadless Area comprises 4600 acres in the Chattahoochee National Forest in Rabun County, Ga., and 3200 acres in the adjoining Nantahala National Forest, Macon County, N.C., in the eastern Blue Ridge Mountains (fig. 1). The highest altitude is about $4170 \mathrm{ft}$ on Chinquapin Mountain at the northern edge of the area; the lowest is about $1600 \mathrm{ft}$ in the West Fork of the Chattooga River, at the southern end of the area. The terrain is heavily forested and is characterized by rugged topography with sharp to rounded ridge crests capping steep valley slopes. In the southern part of the roadless area the topography is dominated by the cliff-bound walls of the deeply incised West Fork of the Chattooga River and its tributary, Overflow Creek, which drains the area and from which the area takes its name.

The roadless area is centered about $4 \mathrm{mi}$ southwest of Highlands, N.C., and about $12 \mathrm{mi}$ northeast of Clayton, Ga. (fig.1). Access to the area is via North Carolina Route 106, wich forms the northern boundary, and by Georgia and North Carolina Route 28 , which is several miles to the east. U.S. Forest Service roads $86 \mathrm{~B}, 86 \mathrm{D}$, and 79 provide access to parts of the roadless area interior.

\section{Previous studies}

Parts of the roadless area have been included in broadly focused regional overviews by numerous workers since the turn of the century. Yeates and 


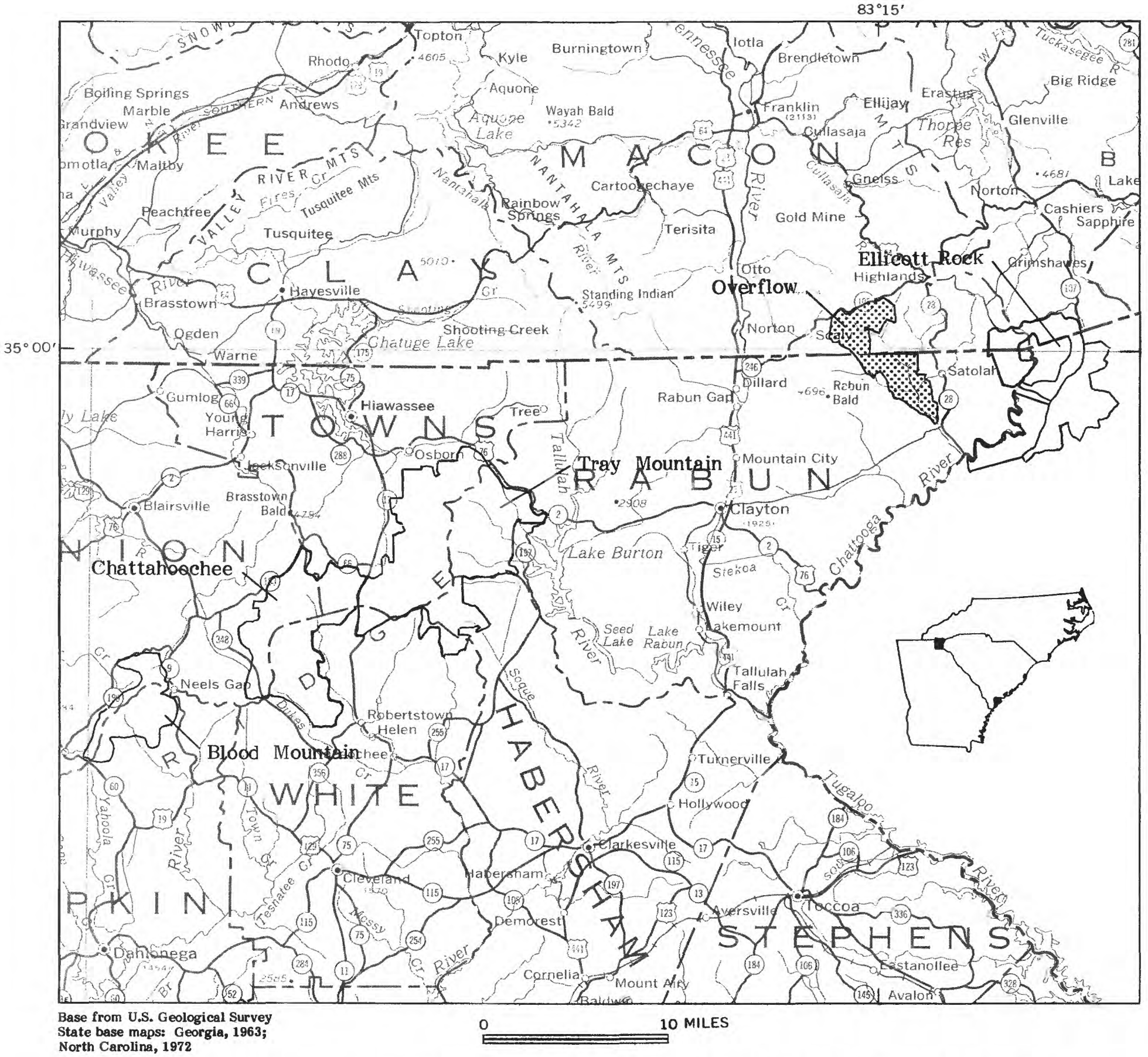

Figure 1.--Index map showing the Overflow Roadless Area (shaded), the Blood Mountain, Chattahoochee, and Tray Mountain Roadless Areas, and the nearby Ellicott Rock Wilderness and additions. 
others (1896) and Jones (1909) described the gold deposits and mining properties of Georgia, including mines and prospects just outside the roadless area. Furcron and Teague (1943) described the mica-bearing pegmatites in Georgia, and Lesure and Shirley (1968) reported on the pegmatites in the southern Appalachian Mountains. King (1894), Pratt and Lewis (1905), Hopkins (1914), and Hartley (1973) discussed ultramafic deposits in the general region. Ferguson (1978) and the U.S. Department of Energy (1979) presented regional studies and evaluations of uranium potential for the southern United States under the National Uranium Resource Evaluation Program (NURE). Keith (1907) mapped the nearby Pisgah quadrangle, N.C., and Crickmay (1952) and Hurst (1973) described the rocks in North Carolina as part of the general descriptions of the geology of the Blue Ridge crystalline rocks. Teague and Furcron (1948) mapped the geology of Rabun and Habersham Counties, Ga. McKniff (1967) made a geologic study of the Highlands-Cashiers area, North Carolina, and Hadley and Nelson (1971) mapped the geology of the Knoxville 2-degree quadrangle, in which part of the Overflow Roadless Area lies. Hatcher (1972, 1974, 1976, and 1978) mapped and reported on various aspects of the geology in the region. The general geology of part of the roadless area is shown on the Geologic Map of Georgia (Georgia Geological Survey, 1976).

\section{Present studies}

G. C. Gazdik and M. P. Davis made field studies for the U.S. Bureau of Mines (USBM) in April 1980, collecting samples of rock, locating mineral prospects, and making reconnaissance scintillometer surveys (Davis, 1982). Fourteen rock and six pan-concentrate samples were collected in the roadless area. Analyses were performed at the USBM, Reno Research Center, Reno, Nev.

Koeppen and Nelson, assisted by C. M. Sears and $\mathrm{K}$. R. Bond, mapped and sampled the roadless area for the U.S. Geological Survey (USGS) during December 1981 and January 1982. They prepared a reconnaissance geologic map and collected pan concentrates, fine-grained stream-sediment samples, and rock-chip samples for a geochemical evaluation (Nelson and Koeppen, in press; Koeppen and Nelson, in press). The samples were analyzed for 31 elements by means of semiquantitative spectrography, for gold and zinc by atomic absorption methods, and for uranium by fluorometric methods at the USGS laboratories, Denver, Colo. (data in Detra and others, 1983).

\section{SURFACE- AND MINERAL-RIGHTS OWNERSHIP}

The Federal Government owns all surface and mineral rights in the Overflow Roadless Area. There are currently no outstanding prospecting or mining permits nor have there been any recent applications.

\section{GEOLOGY}

The Overflow Roadless Area is underlain by highly deformed and metamorphosed rocks of the Tallulah Falls Formation of Late Proterozoic and (or) early Paleozoic age (Galpin, 1915; Hatcher, 1971,
1974). This formation forms a part of the Hayesville thrust sheet, which together with the underlying Great Smoky thrust sheet composes a large part of the allochthonous southern Blue Ridge Mountains. In Georgia and adjoining North Carolina the Hayesville sheet was emplaced by westward-directed transport over the Great Smoky sheet along the Hayesville-Fries thrust fault (Hatcher, 1971). The Overflow Roadless Area is in the eastern part of the Hayesville sheet; rocks of the Great Smoky thrust sheet are not exposed in the roadless area.

The principal rocks exposed in the roadless area are biotite-muscovite gneiss and schist, fine-grained biotite-feldspar gneiss, amphibolite, feldspathic and argillaceous metasandstone, and minor quartzite (fig. 2) (Nelson and Koeppen, in press). Bedding is seldom preserved in these metasedimentary rocks and the most prevalent structure is a discontinuous compositional layering. Numerous variably sized bodies of granite, granodiorite gneiss, and migmatite are present, and discontinuous veins and pods of pegmatite and quartz are widespread.

Even though ultramafic rocks have not been observed within the roadless area, they are present nearby, and hence may exist as small undetected pods within it. A variety of ultramafic and mafic rocks are widely dispersed throughout the Hayesville thrust sheet as small discontinuous outcrop-size pods as well as some large bodies covering many acres (Hadley and Nelson, 1971). These rocks are chiefly serpentinite, dunite, pyroxenite, gabbro, and amphibolite (Hartley, 1973). Locally, some of these rocks are rich in magnetite.

Rocks exposed in the Overflow Roadless Area have been complexly folded, some exposures showing deformation by three generations of folding. Numerous thrust faults are common in the southern Appalachian Mountains (Rodgers, 1953; King, 1964; Hadley and Nelson, 1971; and Hatcher, 1971 and 1972), but faults displacing map units in the Hayesville thrust sheet within the roadless area have not been observed. Minor shear zones and faults, however, having relatively small displacements too small to be shown at the map scale, have been seen in individual exposures.

Generally, the metamorphic rocks in the Hayesville thrust sheet range from the kyanite to sillimanite grade of Barrovian regional metamorphism. In the roadless area, however, aluminous rocks that are compositionally favorable for developing index minerals are not widespread, so metamorphic index minerals are rarely seen and isograds are hard to differentiate. Nevertheless, sillimanite is present locally in the roadless area and rock assemblages of nearby areas in the Hayesville sheet contain sillimanite or kyanite. In the southern Appalachian Mountains the regional thermal metamorphic peak was approximately 450-480 m.y. ago, during the Taconic orogeny (Butler, 1972). Formation of pegmatites, felsic segregations, anatectic melt material, and migmatites in rocks of the roadless area probably occurred at this time, near the peak of regional metamorphism.

\section{GEOCHEMICAL SURVEY}

No known metallic mineral deposits exist in the Overflow Roadless Area. The Hall County gold belt, 


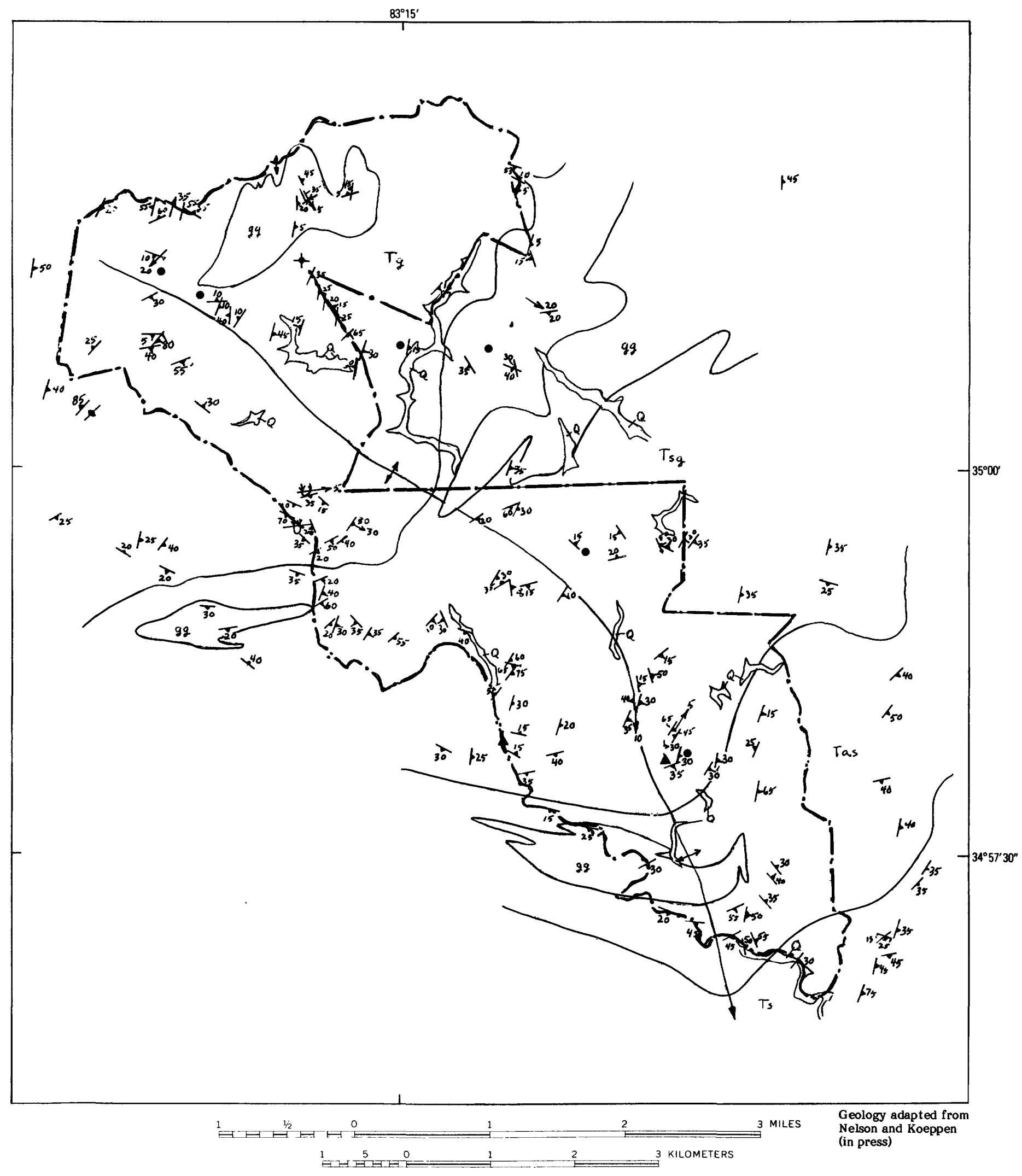

Figure 2.--Geologic map describing mineral resource potential for each geologic unit in the Overflow Roadless Area. 


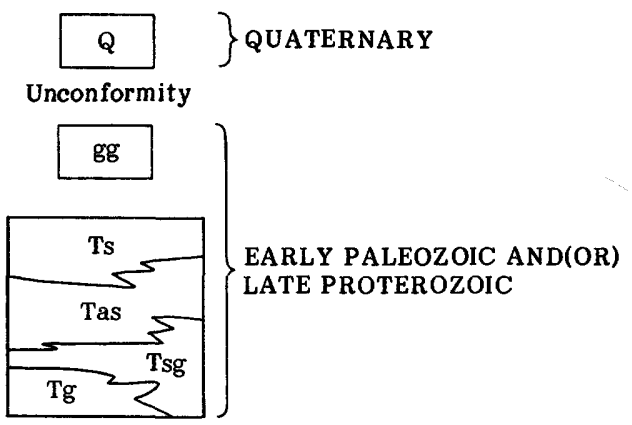
gravels, sand, and clay

Granite and granodiorite gneiss, undivided-Contains small layers and lenses of biotite gneiss, mica schist, and metasandstone; pods and veins of quartz and pegmatite common. Materials suitable for use as crushed stone

Tallulah Falls Formation (Early Paleozoic and(or) Late Proterozoic)-Unnamed biotite gneiss, biotite schist, muscovite-biotite schist, muscovite schist, amphibolite, and metasandstone

Chiefly muscovite schist interlayered with biotitemuscovite schist and minor metasandstone; small quartz and pegmatite veins common. Suitable for use as crushed stone

Interlayered assemblage of amphibolite, biotite schist, biotite-muscovite schist, and metasandstone; includes some granite gneiss. Has many irregular lenses and stringers of quartzo-feldspathic segregations, and has quartz and pegmatite pods and veins. Suitable for use as crushed stone

Tsg Mostly biotite schist and muscovite-biotite schist interlayered with biotite gneiss, minor metasandstone, some granitic gneiss and rarely amphibolite. Variably sized pods and veins of pegmatite and quartz common. Suitable for use as crushed stone

Tr Principally biotite gneiss irregularly interlayered with granite gneiss, and migmatite; includes minor metasandstone that is locally gneissic, mica schist, and amphibolite. Variably sized veins and pods of both pegmatite and quartz are widespread. Rocks locally suitable for crushed stone and nondimensional uses

Contact, approximately located

L25 Strike and dip of layering and foliation

Strike and dip of foliation

$\stackrel{25}{2}$ Strike and dip of cleavage

$\longrightarrow$ Bearing and plunge of lineation; may be combined with foliation

$\stackrel{4}{\longrightarrow}$ Anticline, showing plunge direction

+ Minor overturned synform

$\uparrow$ Horizontal foliation

$\rightarrow \quad$ Vertical foliation

Approximate boundary of roadless area

- Rock sample locality having $\mathbf{0 . 0 5}$ ppm gold

- Fine-grained stream-sediment sample locality having 0.1 to $0.25 \mathrm{ppm}$ gold 
where placers have been prospected and worked since the 1800 's, is just east of the roadless area; and although our reconnaissance geochemical sampling found scattered traces of gold and silver in rock and fine-grained stream-sediment samples (fig. 2), there were no concentrations that might be related to significant mineralization in the area (Koeppen and Nelson, in press).

The geochemical evaluation is based on an analysis of the trace-element content of 78 samples of rock, 58 samples of fine-grained stream sediment, and 39 heavy-mineral pan concentrates from streams. The geochemical data for the roadless area samples have been listed by Detra and others (1983). Traces of gold (0.05 to 0.25 parts per million [ppm] ) and silver $(0.0$ to $0.5 \mathrm{ppm}$ ) were detected in two fine-grained streamsediment samples and in six rock samples, but gold and silver were not detected in any of the pan concentrates. Considering the lack of gold in all the other samples from the roadless area, even the relatively few rock samples containing gold can be regarded as anomalous. Their scattered distribution and low concentration suggest they represent only small localized pockets or thin veinlets of fine-grained gold, possibly concentrated by fluid movement during regional metamorphism. No other anomalous geochemical concentrations were recognized in the roadless area.

\section{ASSESSMENT OF MINERAL RESOURCE POTENTIAL}

The Overflow Roadless Area has a low potential for crushed stone, and contains minor amounts of lowquality mica and amethyst gemstone. Traces of gold (0.25 ppm or less) in a small number of rock-chip or fine-grained stream-sediment samples (fig. 2) are probably related to small, weakly mineralized pockets and indicate only a low resource potential. No geochemical or mineralogical evidence was found during the geochemical survey to suggest hidden deposits of other metallic minerals in the area.

\section{Crushed stone}

Gneiss and schist in the roadless area are suitable for use as crushed rock, aggregate, or other construction materials (figs. 2, 3). These rocks are abundantly available outside the area from more readily accessible sites and existing quarries.

\section{Mica}

Greenish-brown, bent, and ruled mica occurs in the pegmatite at numerous scattered localities near the roadless area (fig. 3). The area includes a part of the Rabun pegmatite district, a region of poorly exposed and weathered pegmatites (Lesure and Shirley, 1968). A small number of the sites noted as prospects on the USGS 1:24,000-scale topographic maps of the area correspond to the largest pegmatite occurrences, which all are small and of low quality; the resource potential for mica is considered to be low in the roadless area.

\section{Gold}

The Overflow Roadless Area lies immediately west of the Hall County gold belt, a 2-mi-wide band of isolated auriferous quartz veins and associated stream placers (fig. 3). Most mining activity in the belt occurred between 1840 and 1890 (Yeates and others, 1896), and although production records for the belt are extremely sketchy, it appears that the amount of gold removed from the six prospects near the roadless area was relatively small. The total recorded production for Rabun County for the period 1881-1904, according to U.S. Mint Records, is only 1,730 oz of gold.

All samples collected by the USGS in the roadless area were analyzed spectrographically for gold; the fine-grained stream sediments and the rock chips were also analyzed by atomic-absorption method (AA), but inadequate sample material was collected for AA analyses of gold in the fraction of the pan concentrates that was analyzed. Six rock-chip samples (four of gneiss, and two of pegmatite) contain 0.05 ppm gold, the lower detection limit for the AA technique used. The several samples of quartz vein that we analyzed are barren. Samples of fine-grained sediment from two streams contain 0.1 and $0.25 \mathrm{ppm}$ gold, respectively. The gold-bearing samples are from scattered lcoations in the area and apparently do not define any restricted pattern of distribution. In consideration of the lack of gold in all other samples, the few samples with detectable gold can be regarded as anomalous. Because the gold-bearing samples are both widely scattered and of low concentration, it would appear that each probably represents only localized, low-grade mineralization. Considering the sparse distribution of the concentrations, the amount of data is minimal for a statistical generalization. The potential for gold resources within the roadless area, nevertheless, is estimated to be low.

\section{Thorium and uranium}

The Overflow Roadless Area is partly within the mountain monazite belt of Mertie (1979, p. 66), a long and generally narrow band of monazite-bearing crystalline rocks locally consisting of granite, granite gneiss, pegmatites, and biotite gneiss. Several early reports were made on monazite in placers east of the roadless area (probably Hedden Placer-Yeates and others, 1896; Sterrett, 1907), but no production of monazite is known or recorded. Our spectral scintillometer survey identified one small area $\left(50 \mathrm{ft}^{2}\right)$ having higher-than-background emission at the confluence of Holcomb and Overflow Creeks. Sediment and bedrock samples from this site and from nearby streams did not yield anomalous concentrations of thorium and rare-earth elements (semiquantitative spectrographic analyses), or uranium (AA), and only a moderate amount of monazite and zircon was present in the samples. Low thorium and uranium contents of most samples, and the general lack of substantial gravel as host for the monazite, are not indicative of a potential for uranium and thorium in the roadless area.

\section{Oil and gas}

Recent seismic studies (Cook and others, 1979; Harris and others, 1981) indicate that the metamorphic rocks forming the Blue Ridge Mountains of North Carolina and adjoining Georgia were emplaced by westward-directed thrust faulting over a thick sequence $(3,000-15,000 \mathrm{ft})$ of potentially hydrocarbonbearing sediments. On the basis of the seismic profiles, the sediments probably occur at depths of as 


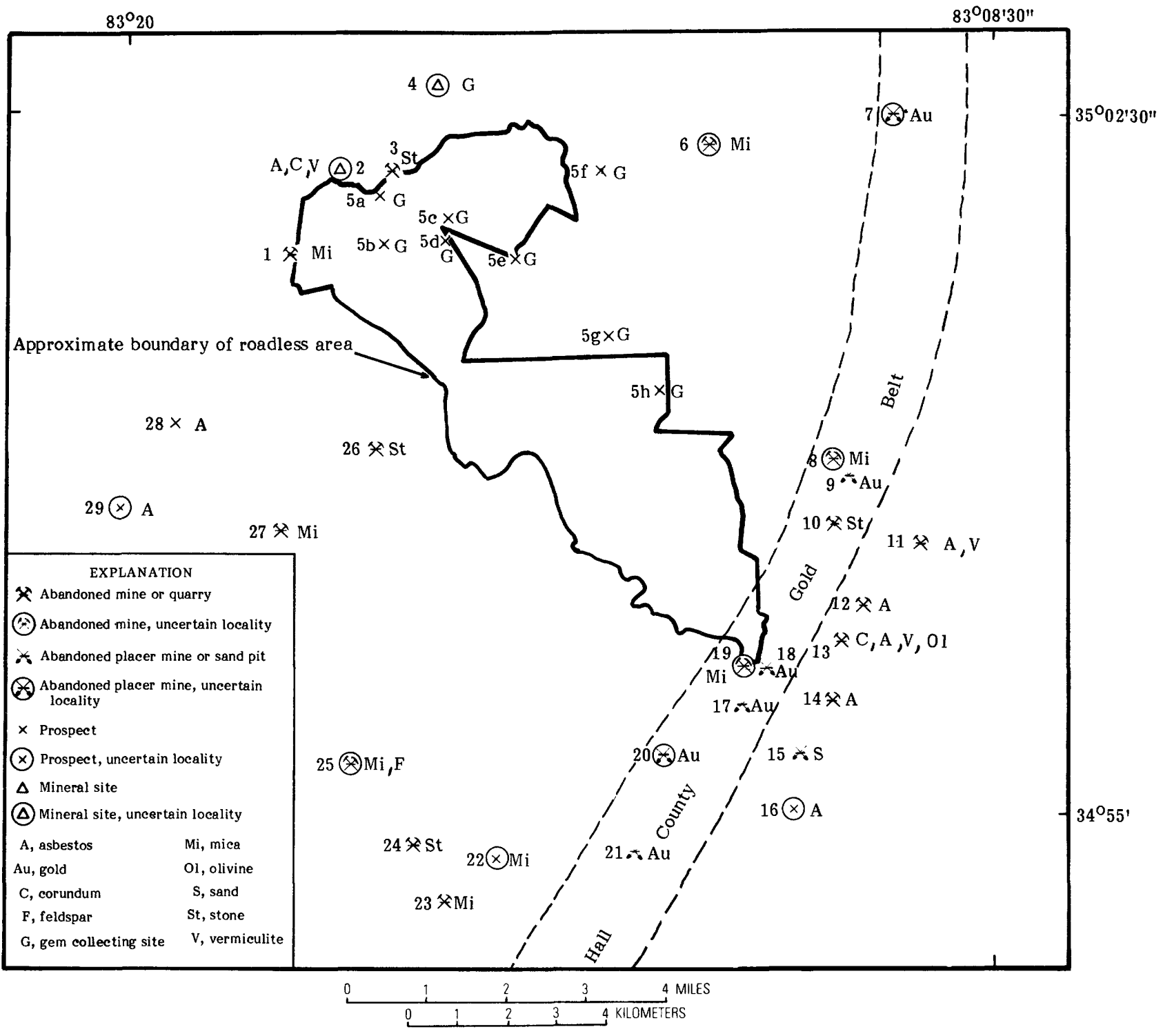

Figure 3. Mines, prospects, and mineral localities in the Overflow Roadless Area and vicinity. Numbers are keyed to descriptions in table 1 (see accompanying map). 
much as $5 \mathrm{mi}$ below the surface. High temperature at such depths limits the likelihood of hydrocarbons occurring there, but if present they are probably in the form of natural gas. No reasonable estimate of potential for gas in the roadless area can be made with available information; deep drilling would be necessary before estimates of potential can be made.

\section{REFERENCES CFTED}

Butler, J. R., 1972, Age of Paleozoic regional metamorphism in the Carolina, Georgia, and Tennessee southern Appalachians: American Journal of Science, v. 272, no. 4, p. 319-333.

Conley, J. F., 1958, Mineral localities of North Carolina: North Carolina Division of Mineral Resources Information Circular 16, 83 p.

Cook, F. A., Albaugh, D. S., Brown, L. D., Kaufman, Sidney, Oliver, J. E., and Hatcher, R. D., Jr., 1979, Thin-skinned tectonics in the crystalline southern Appalachians; COCORP seismicreflection profiling of the Blue Ridge and Piedmont: Geology, v. 7, no. 12 , p. 563-567.

Crickmay, G. W., 1952, Geology of the crystalline rocks of Georgia: Georgia Geological Survey Bullet in 58, 54 p.

Davis, M. P., 1982, Mineral resources of Overflow Further Planning Area, Rabun County, Georgia and Macon County, North Carolina: U.S. Bureau of Mines Open-file Report MLA 31-82, 39 p.

Detra, D. E., Domenico, J. A., Adrian, B. M., Koeppen, R. P., and Nelson, A. E., 1983, Geochemical analyses and descriptions of geochemical samples from Overflow Roadless Area, Rabun County, Georgia, and Macon County, North Carolina: U.S. Geological Survey Open-file Report [ in press] .

Ferguson, R. B., 1978, Savannah River Laboratory hydrogeochemical and stream sediment reconnaissance, preliminary raw data release, Greenville $1^{\circ} \times 2^{\circ}$ NTMS area, Georgia, North Carolina, and South Carolina: National Uranium Resource Evaluation Program, U.S. Department of Energy, DPST-78-146-2, p. A1-A13.

Furcron, A. S., 1960, Corundum in Georgia: Georgia Geological Survey Mineral Newsletter, v. 13, no. 4, p. 173.

Furcron, A. S., and Teague, K. H., 1943, Mica-bearing pegmatites of Georgia: Georgia Geological Survey Bulletin 48, 192 p.

Galpin, S. L., 1915, A preliminary report on the feldspar and mica deposits of Georgia: Georgia Geological Survey Bulletin 30, 190 p.

Georgia Geological Survey, 1976, Geologic map of Georgia: Georgia Geological Survey Map GM-7, scale $1: 500,000$.

Hadley, J. B., and Nelson, A. E., 1971, Geologic map of the Knoxville quadrangle, North Carolina, Tennessee, and South Carolina: U.S. Geological Survey $M$ iscellaneous Geologic Investigations Map 1-654, scale 1:250,000.

Hartley, M. E., III, 1973, Ultramafic and related rocks in the vicinity of Lake Chatuge: Georgia Geological Survey Bulletin 85, 61 p.

Harris, L. D., Harris, A. G., de Witt, Wallace, Jr., and Bayer, K. C., 1981, Evaluation of southern eastern overthrust belt beneath the Blue RidgePiedmont thrust: American Association of
Petroleum Geologists Bulletin, v. 65, no. 12, 2497-2505.

Hatcher, R. D., Jr., 1971, The geology of Rabun and Habersham Counties, Georgia: Georgia Geological Survey Bulletin 83, 48 p.

1972, Developmental model for the southern Appalachians: Geological Society of America Bulletin, v. 83, no. 9, p. 2735-2760.

1974, Introduction to the tectonic history of northeastern Georgia: Georgia Geological Survey Guidebook 13-A, p. 59-60.

1976, Introduction to the geology of the Eastern Blue Ridge of the Carolinas and nearby Georgia: Carolina Geological Society Guidebook, 53 p. 1978, Structural style of the Blue Ridge: Geological Society of America Penrose Research Conference Field Trip.

Hopkins, O. B., A report on the asbestos, talc, and soapstone deposits of Georgia: Georgia Geological Survey Bulletin 29, 319 p.

Hunter, C. E., 1941, Forsterite olivine deposits of North Carolina and Georgia: Georgia Geological Survey Bulletin 47, $117 \mathrm{p}$.

Hunter, C. E., and Mattocks, P. W., 1936, Vermiculites of western North Carolina and north Georgia: Tennessee Valley Authority, Division of Geology Bullet in $5,10 \mathrm{p}$.

Hurst, V. J., 1973, Geology of the southern Blue Ridge Belt: American Journal of Science, v. 273, no. 8, p. 643-670.

Jones, S. P., 1909, Second report on the gold deposits of Georgia: Georgia Geological Survey Bulletin $19,283 \mathrm{p}$.

Keith, Arthur, 1907, Description of the Pisgah quadrangle [North Carolina-South Carolina] : U.S. Geological Survey Geologic Atlas, Folio 147.

Kerr, W. C., and Hanna, G. B., 1888, Ores of North Carolina, in The Geology of North Carolina: North Carolina Geological Survey, v. 2, chap. 2, p. 123-359.

King, F. P., 1894, A preliminary report on the corundum deposits of Georgia: Georgia Geological Survey Bulletin 2, $138 \mathrm{p}$.

King, P. B., 1964, Geology of the central Great Smoky Mountains, Tennessee: U.S. Geological Survey Professional Paper 349-C, 148 p.

Koeppen, R. P., and Nelson, A. E., in press, Geochemical survey of the Overflow Roadless Area, Rabun County, Georgia, and Macon County, North Carolina: U.S. Geological Survey Miscellaneous Field Studies Map MF-1618-C.

Lesure, F. G., and Shirley, L. E., 1968, Mica, in Mineral resources of the Appalachian region: U.S. Geological Survey Professional Paper 580, p. 311-325.

Lewis, J. V., 1896, Corundum and the basic magnesian rocks of western North Carolina: North Carolina Geological Survey Bulletin 11, 107 p.

McKniff, J. M., 1967, Geology of the HighlandsCashiers area, North Carolina, South Carolina, and Georgia: Houston, Texas, Rice University, unpublished Ph.D. dissertation, 100 p.

Mertie, J. B., Jr., 1979, Monazite in the granitic rocks of the southeastern Atlantic states-an example of the use of heavy minerals in geologic exploration: U.S. Geological Survey Professional Paper 1094, 79 p.

Nelson, A. E., and Koeppen, R. P., in press, Geologic map of the Overflow Roadless Area, Rabun 
County, Georgia, and Macon County, North Carolina: U.S. Geological Survey Miscellaneous Field Studies Map MF-1618-B.

Pratt, J. H., and Lew is, J. V., 1905, Corundum and the peridotites of western North Carolina: North Carolina Geological Survey Bulletin 1, $464 \mathrm{p}$.

Rodgers, John, 1953, Geologic map of east Tennessee with explanatory text: Tennessee Division of Geology Bullet in 58, part 2, 168 p.

Sterrett, D. B., 1907, Monazite, in U.S. mineral resources, 1906: U.S. Geological Survey, p. 966. 1923, Mica deposits of the United States: U.S. Geological Survey Bulletin 740, 342 p.

Teague, K. H., 1956, Georgia [asbestos] occurrences described: Georgia Mineral Newsletter, v. 9, no. 1, p. 4-7.

Teague, K. H., and Furcron, A. S., 1948, Geology and mineral resources of Rabun and Habersham Counties, Georgia: Georgia Geological Survey and Tennessee Valley Authority map, scale 1:126,720.

U.S. Department of Energy, 1979, National uranium resource evaluation interim report: GJO-111(79), p. 113-121.

Yeates, W. S., McCallie, S. W., and King, F. P., 1896, A preliminary report on a part of the gold deposits in Georgia: Georgia Geological Survey Bulletin 4-A, 542 p. 
